\title{
RED FOX IN SOUTHWESTERN SASKATCHEWAN
}

\author{
by Terry Wedge, Saskatoon
}

Although Burt and Grossenheider's A Field Guide to the Mammals shows all of Saskatchewan as within the range of the Red Fox, there have been apparently no records of Red Fox in extreme southwestern Saskatchewan. W. H. Beck's Guide to Saskatchewan Mammals (1958) states that "there are few or no individuals in the southwest portion." I wish to record one which was seen while I was working for the Saskatchewan Museum of Natural History (archaeological expedition) in the summer of 1960 near
Gull Lake. On July 10 of that year several of us saw a Red Fox running parallel to the road on which we were travelling, and possibly thirty or forty yards from our car, and on a field which was very lightly vegetated. Several of us saw it and none of us doubted at all that it was a Red Fox. Not knowing the importance of the observation at the time we neglected to record the location, but it was within approximately a three mile radius of section 5 , township 12 , range 19 , west of the third meridian.

\section{Notes and Letters}

\section{BEAVER ON THE TREELESS PLAINS}

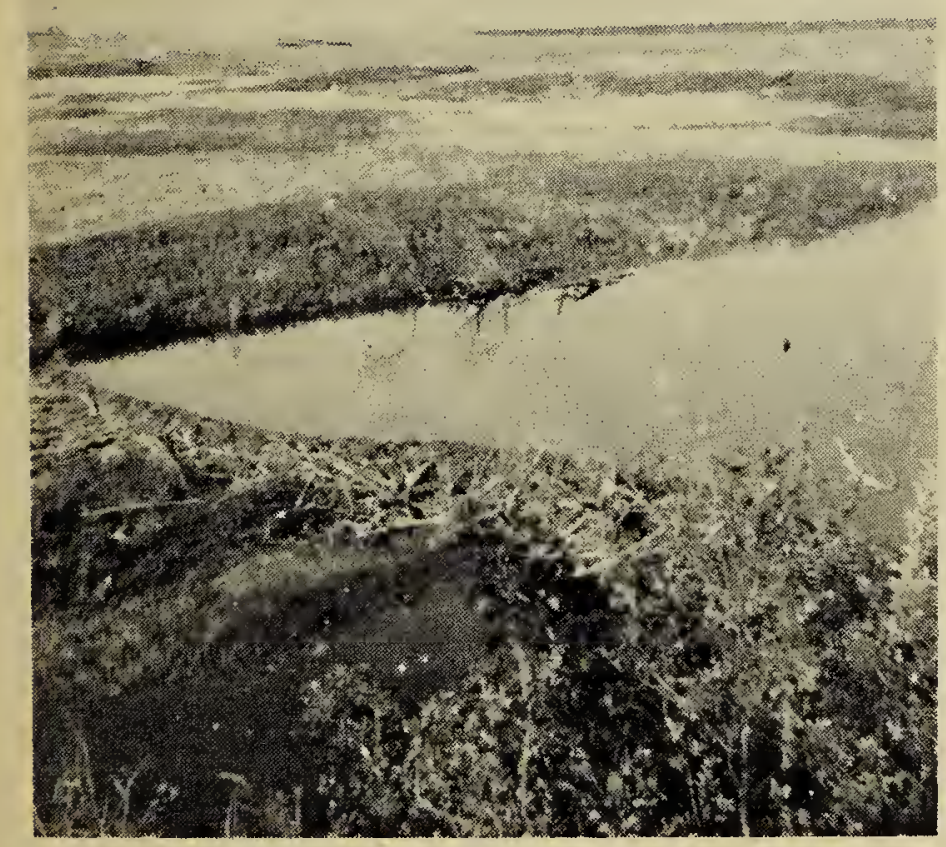

It was a Sunday evening in late spring of 1961 that we drove out to the Greenfield farm, southwest of Nokomis, to see the beaver dam. We not only found the dam, but we were introduced by the Greenfields to their miniature wildlife preserve, appropriately close to the oldest wildfowl preserve on the North American continent, the Last Mountain Lake Bird Sanctuary.

The dam was a very real beaver dam, and very sturdy. Two beavers had moved in the previous summer (1960) through a chain of creeks, from somewhere up north, and late that July they began building the dam. Then they left and returned again in the spring of 1961 , to complete their project. The water behind the dam is about eight or nine feet deep, and the beaver family have constructed their dam in such a manner that they have about four feet of water below the dam in which they can swim about with their offspring. The family increased by two in the spring of the year.

About 500 feet downstream, they constructed a secondary dam to take tho pressure off the main dam, and a further 75 to 100 yards around the next bend lay another dam. The beavers made a slide for themselves where they could tumble freely down the steep 25-foot bank with green poplar and willow branches they used to build their dam.

Late in 1961, the beaver family moved to a new location, one mile to the east, where a more plentiful supply of water existed. They built a new domicile, and the solicitous Greenfield brothers hauled poplar logs, boughs and branches to the top of the bank. "In short order," said Ab Greenfield, "the beavers dragged them down to the water." And now the beaver and their offspring are cozy and contented for the winter.Edy the Humphreys, Nokomis. 